\title{
Empowering to Improve Submission of Claim Process in Local Shipyard, in Malaysia
}

\author{
Azman Ismail ${ }^{\mathrm{a}^{*}}$, Nor Hasni Osman ${ }^{\mathrm{b}}$ \\ ${ }^{a}$ Othman Yeop Abdullah, Graduate School of Business, Universiti Utara Malaysia, 06010 UUM Sintok, Kedah, Malaysia \\ ${ }^{b}$ School of Technology Management and Logistics (STML), Universiti Utara Malaysia, 06010 UUM Sintok, Kedah, Malaysia \\ *Corresponding author: azman.ismail@bnsy.com.my
}

\begin{abstract}
This paper study about struggle faces by subcontractor in submitting their work claim due to tedious processes of verification and compilation supporting document for payment process. In order to resolve this problem, the qualitative action research study method was conducted in the shipyard to propose the best solution to overcome this issue. Subcontractor need to play active roles in getting their documentation ready while Shipyard must ensure the claim is valid for payment. Empowerment as one of Business Process Reengineering(BPR) enabler together with IT-based system being chose to overcome this issue while Action Research(AR) as a method being deploy to engage the subcontractor and shipyard staff intervention to come out with more effective solution for this problem.
\end{abstract}

Keywords: Empowerment, business process reengineering, action research, insider action research, qualitative study

(C) 2016 Penerbit UTM Press. All rights reserved

\subsection{INTRODUCTION}

Subcontracting becomes popular solution by most of contractor to resolve their shortage in production resources. However, delay in payment will result in catastrophe issue in relationship between contractor and subcontractor. One of reason, which causes this problem to happen, is due to tedious process in compilation supporting document for payment process (Ramachandra, 2013). Managing effectively subcontracting related issue is part of supply chain process in any organization, and can't be ignored off (Eriksson, 2010; Karim, Marosszeky, \& Davis, 2006).

Before any payment can be released, a proper documentation and validation need to be carry out (Hui, Othman, Omar, Rahman \& Haron, 2011). Shipyard require four document to be compile, approve and verify before it become good to pay; Work Order, Quality Inspection Report(QIR), if any, Statement of Progress(SOP), and Tax Invoices(TI). As subcontracting work is services in nature, SOP become vital certificate to certify the work progress done, and value of money to be claim. Ramachandra (2013) mentioned that Latham wrote in his report "Trust and Money", "subcontractor worry their certified monthly payment (SOP) will not properly have reflected the value of work being done", this will end up with SOP late to be issued to subcontractor (due to disputing of percentage progress and getting approval) for subcontractor claiming purposes.

In shipyard current practices, the SOP took thirty-three (33) days to be approved manually by workshop, production, and project manager. Another fourteen days (14) taken to verify, compile and submitted the whole stack of document to finance for payment process. The delays become worse when subcontractor hire a runner to do this compilation rather than manage it by themselves. Shipyard, in collaboration and participation (an AR) with its subcontractors and other departments involved lead an AR project to propose a suitable solution to overcome this issue for betterment of all interested parties.

\subsection{LITERATURE REVIEW}

$\mathrm{AR}$, a cyclical process in four main steps as constructing, planning the action, taking the action, and evaluating the action as per Coghlan and Brannick (2014) being deploy to discuss the propose solution to the shipyard management. An insider element with deep preunderstanding in shipyard context, access to information and data, collaboration and participation with team members took place in various pre discussion to propose the ultimate solution (Coghlan \& Brannick, 2014). In view to resolve the manual SOP approval, an online approval using existing IT-based platform system in Shipyard being extended it usage to subcontractor. The team had proposed the approval of SOP must be made online, and subcontractor can access it from their office to print and compile.

In conjunction to the above objective, BPR as a management tools to radically change the old and manual process being carried out at Shipyard (Hammer \& Champy, 1993). An old work processes with involved cross functional department, being review and revamp. The seven principle of engineering by Hammer (1990) adopted and applied. The importance of process being prioritize rather than functionality on the existing department. All related cross functional department function being reviewed and evaluate on clean slate basis. BPR project implementation step using IT based system as per Davenport and Short (1998) adopted and discuss with IT consultant to come out with the 
blue print of the system.

A systematic process to capture work progress in IT-based system introduced in the work processes. Doing this, the system need the feedback and interaction with its user and requires certain authority given to the staff and subcontractor. The empowerment concept adopted from BPR being deploy to make this system working and functioning (Iqbal, 2012). Any good system can't work well if no authority being given to its user to feed and interact with the system (Anuar \& Radiah, 2010; Bano \& Zowghi, 2015). Engaging in various requirements and external forcing factors, the empowerment must come with responsibility and stringent security setting to protect both side needed for solution, and justify the needs of empowerment (Erstad, 1997; Goksoy, Ozsoy \& Vayvay, 2012; Holt, 2000; Howton \& Fallis, 2003; Iqbal, Nadeem \& Zaheer, 2015).

Erstad (1997) mentioned that Bowen and Lawler define empowerment as an approached to empower staff/subcontractor (user to the system) in making decision. It shows how the management assist and implement the empowerment culture in the organization context. He also stated that Pastor indicate this situation as phenomenon whereby staff/subcontractor (user to the system) taking accountability base own their own action. This meaning emphasis the significance of individual in successfully adaptation to the empowerment practice. Erstad also highlighted that Nixon discussed empowerment arising from internal and external challenges for the organization context. Internal challenges relate to motivation, development, and staff retention, while external challenges refer to levels of competition, changes in composition of workforce and expectation from customer. In conclusion to the definition above, Erstad conclude that empowerment require clear objective, learning and training, participative, tools and correct technique to make it successful.

Holt (2000) also discussed empowerment view by Loretta and Polsky, which is divided to two perspectives. Empowerment on management view is about sharing of control and additional knowledge, while from staff/subcontractor (user to the system) is about acceptance of risk by taking up more responsibility. Holt also stress that empowerment being collectively define as process giving the staff/subcontractor (user to the system) to make an action and decision with regards to their functions and work processes, within limit of authority and responsibility provided by the management.

Empowerment also can be understood as what Lewin and his associates mentioned about group decision making and selfmanagement (Burnes, 2007). It's also being describe as more striving and purer perceptions of participation and democracy (Greenwood \& Levin, 2007). When shipyard seek to change a processes within its organization, Shipyard is fully aware that automation and staff/subcontractor (user to the system) empowerment will evolve together and required detailed attention from the management (Harmon, 2015).

Reason (2006) mentioned that, Rahman suggested AR can influence to promote empowerment of people with it democratic participation and voice in society and community. A cyclical AR cycle being adopted within subcontractors and Shipyard (researchers and department concern) to discuss and propose a solution to get the SOP approved faster.

Empowerment can be seen extremely embedded in AR in term of its egalitarian notion when researcher and staff/subcontractor (user to the system) engage together in respective AR cycle (MacIntosh \& Bonnet, 2007). Empowerment also, as part of BPR enabler will push it decision making to the lower levels, thus create a culture in which staff/subcontractor (user to the system) feel more responsible and accountable (Maull et al., 2003) though empowerment need continues and careful training to those concern (Alsudairi, 2013).

In conclusion, to overcome the hassle of approving the SOP manually, Shipyard had implemented an online approval system which enable the subcontractor to print and compile the document from their own office. To make the system functioning well, an empowerment being given to staff/subcontractor to interact, making decision from their action, and be responsible to it. Emancipatory approach in AR method fostering the empowerment and enable the system to serve its user better.

\subsection{METHODOLOGY}

This research used qualitative AR method in collaboration and participation between subcontractor and shipyard staff. The Researcher, which also a complete team member to this setup, involve directly in the existing business process to be revamp and reengineered. Two main document used for supporting the payment process i.e. QIR and SOP being put online in term of approval, accessibility, and empowerment to manage the document to subcontractor.

This research is based on a single longitudinal study of the Shipyard that took place from Oct 2013 to April 2016. The design of this research based on framework proposed by Zuber-Skerritt and Perry (2002). The core AR project which emphasis on proposing and building the new system took place from Oct 2013 until Feb 2015. The online system officially being used after April 2015 and data being collected up to April 2016 which involve three different consecutive repair project. A total of 946 SOP being collected and analyze.

The SOP represent seven subcontractors which involved in all 3 new repair project after system successfully go live. Project Repair

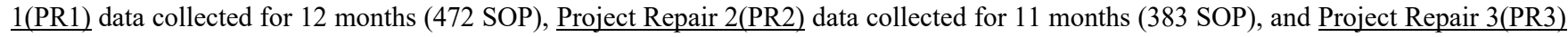
data collected for 8 months (91 SOP). Each SOP will indicate days taken to approve the online SOP by approver of the system, i.e. Head of Workshop, Head of Production, Project Manager, and Head of Ship repair. Results from Project Repair 1 will indicate benchmark on approval days, while results from Project Repair 2 and 3 will validated the benchmarking. The approval days taken being group up in term of i) approved less than 2 days, ii) approved within 3-4 days, iii) approved within 5-6 days, and iv) approved more than 7 days.

\subsection{ONLINE PROCESSES}

The online processes work by way of Production Planning capturing the work progress in the system. The work progress come from daily and weekly report produce by subcontractor base on work planning/job ticket issued by Production Planning. At this stage, the validity and dispute on percentage of work progress collectively being agreed upon. Way back, during commercial negotiation stage, Subcontractor and Shipyard agreed with the pay plan schedule that indicate at what percentage the SOP to be issue and approve. When cumulative progress reached percentage progress of SOP to be issue, system will trigger and send the email to the SOP approver to approve the progress. After SOP completely approve by approver, the system will notify the subcontractor on the availability of the SOP to be print out. The same goes to QIR, once approved by Quality officer, the system will notify the subcontractor through email on the availability of the report. 
Subcontractor, from their own office will log in to the online system and print the SOP and QIR. Once printed, the print option will be disable from the online system. This is part of security setting implement as both of the document are valid for payment. Only 1 copy are allowed to be print out from system and submit for payment. Should there is troublesome during printing and subcontractor unable to print, they will call system helpdesk to release the print option with written justification and event log by system. The general idea of this new system is to allow the SOP and QIR approver to approve their document online. Once approve, this document can be access online by subcontractor, and allow them to print it from their office and do the compilation straight away to submit for claiming purposes.

\subsection{RESEARCH FINDINGS}

From this research, we have collected 946 SOP (completely approve) base on sampling for this project. The approval days being grouped to 4 categories as per Table 1.1. PR1 show that 73\% of SOP approved in 0-2 days, $16 \%$ of SOP approved in 3-4 days, 7\% approved in 5-6 days and $4 \%$ approved more than 7 days. The results form PR1 become benchmark for SOP approval days using this online system.

Table 1 SOP approval days

\begin{tabular}{lccccc}
\hline Project Name & $\mathbf{0 ~ - ~ 2 ~ d a y s ~}$ & $\mathbf{3 - 4}$ days & $\mathbf{5 - 6}$ days & T days & 18 \\
\hline Project Repair 1(PR1) & 345 & 76 & 33 & 24 & 23 \\
Project Repair 2(PR2) & 254 & 82 & 17 & 772 \\
Project Repair 3(PR3) & 24 & 43 & 383 & 91 \\
\hline
\end{tabular}

This benchmark further validated with results from PR2 and PR3. PR2 shows that $67 \%$ of SOP approved in $0-2$ days, $21 \%$ of SOP approved in 3-4 days, 6\% approved in 5-6 days and 6\% approved more than 7 days. Results in PR3 stated that 26\% of SOP approved in 0-2 days, $47 \%$ of SOP approved in 3-4 days, $19 \%$ approved in 5-6 days and 8\% approved more than 7 days.

From all the findings in PR1, PR2, and PR3 66\% of SOP approved in 0-2 days, 21\% of SOP approved in 3-4 days, $8 \%$ approved in 5-6 days, and 5\% approved more than 7 days. It can be seen that online approval had reduce the SOP approval days significantly from 33 days to max 0-2 days. PR1 and PR2 show more than 65\% of SOP can be approve within 0-2 days while results in PR3 lowered to $23 \%$ only due to shorter month for data collection and change in approver personal in project setup.

The online system with empowerment to the shipyard staff/subcontractor in capturing and validating the work progress, allow the SOP to be approved faster (online approval) and make it possible for subcontractor to compile their document claims earlier (access from office). What the subcontractor need to do now is submit this validated and approve document for their payment processes at Shipyard finance department.

\subsection{DISCUSSION AND CONCLUSION}

Empowerment is a great deal to self-educated the subcontractor in compiling and submitting their claim effectively. Through this, they can manage the necessary supporting document wisely and in know how why their claim can't be paid. Empowering also instill self-belonging and prosper learning in managing the cash flow for the subcontractor/organization. With this concept, problematic concerns of manual approval in Shipyard with took too long to be approve now can be easily verify, approved, access, and submit for claiming and payment process. Empowerment criteria with added emphasis on responsibility and sense belonging will allow both Shipyard and subcontractor to close up their ties and working effectively in now and future business.

\subsection{ACKNOWLEDGEMENT}

This research was financially supported by the Ministry of Higher Education under the Industrial PhD program MyBrain 15 with collaboration from a leading Shipyard in Malaysia and Othman Yeop Abdullah, Graduate School of Business, Universiti Utara Malaysia. The author also extends his appreciation to the reviewers for their comments and wishes to sincerely thank all related parties that involve in the research study. The author takes responsibility for any typographical errors that went through unnoticed.

\section{References}

Alsudairi, M. A. T. (2013). Analysis and Exploration of Critical Success Factors of ERP Implementation : A Brief Review. International Journal of Computer Applications, 69(8), 44-52.

Anuar, S., \& Radiah, O. (2010). Determinants of Online Tax Payment System in Malaysia. International Journal of Public Information Systems, 6(1), 17-32.

Bano, M., \& Zowghi, D. (2015). A Systematic Review On The Relationship Between User Involvement And System Success. Information and Software Technology, 58, 148-169. http://doi.org/10.1016/j.infsof.2014.06.011.

Burnes, B. (2007). Kurt Lewin and the Harwood Studies: The Foundations of OD. The Journal of Applied Behavioral Science, 43(2), 213-231. http://doi.org/10.1177/0021886306297004

Coghlan, D., \& Brannick, T. (2014). Doing Action Research In Your Own Organization (4th ed.). Sage, London.

Davenport, T. H., \& Short, J. E. (1998). The New Industrial Engineering: Information Technology and Business Process Redesign. IEEE Engineering Management Review, 26(3), 46-59.

Eriksson, P. E. (2010). Improving Construction Supply Chain Collaboration And Performance: A Lean Construction Pilot Project. Supply Chain Management: An International Journal, 15(5), 394-403. http://doi.org/10.1108/13598541011068323 
Erstad, M. (1997). Empowerment and organizational change. International Journal of Contemporary Hospitality Management, 9(7), 325-333. http://doi.org/10.1108/09596119710190976

Goksoy, A., Ozsoy, B., \& Vayvay, O. (2012). Business process Reengineering: Strategic Tool For Managing Organizational Change An Application In A Multinational Company. International Journal of Business and Management.

Greenwood, D. J., \& Levin, M. (2007). Introductions to Action Research: Social Research for Social Change (2nd ed.). Thousand Oaks: Sage Publications.

Hammer, M. (1990). Reengineering Work: Don’t Automate, Obliterate. Harvard Business Review, 68(4), 104-112.

Hammer, M., \& Champy, J. (1993). Reengineering the Corporation. New York, NY: HarperCollins.

Harmon, P. (2015). The Scope And Evolution Of Business Process Management. In Handbook on Business Process Management 1 (pp. 37-80). Springer Berlin Heidelberg.

Holt, G. D. (2000). Constructing Empowerment: People, Processes, Particiption And Profit. In 1st International Conference on Systems Thinking in Management (pp. 245-249). http://doi.org/10.1017/CBO9781107415324.004

Howton, A. J., \& Fallis, A. . (2003). Reform from Within: An Ecological Analysis of Institutionalized Feminism at Our University.

Hui, W. S., Othman, R., Omar, N. H., Rahman, R. A., \& Haron, N. H. (2011). Procurement Issues In Malaysia. International Journal of Public Sector Management, 24(6), 567-593. http://doi.org/10.1108/09513551111163666

Iqbal, J. (2012). Towards a Conceptual Framework For Implementation Of Business Process Reengineering (BPR) Initiative. Interdisciplinary Journal of Contemporary Research in Business, 3(11), 523-550.

Iqbal, N., Nadeem, W., \& Zaheer, A. (2015). Impact of BPR Critical Success Factors On Inter-Organizational Functions: An Empirical Study. The Business \& Management Review, 6(1), 152-165.

Karim, K., Marosszeky, M., \& Davis, S. (2006). Engineering , Construction and Architectural Management Article information: Engineering, Construction and Architectural Management, 13(1), 27-42.

MacIntosh, R., \& Bonnet, M. (2007). International Perspectives On Validity In Action Research: Introduction To The Special Issue. Management Research News, $30(5), 321-323$

Maull,R. S., Tranfield, D. R., \& Maull, W. (2003). Factors Characterising the Maturity of BPR programmes. International Journal of Operations \& Production Management, 23(6), 596-624. http://doi.org/10.1108/01443570310476645

Ramachandra, T. (2013). Exploring Feasible Solutions To Payment Problems In The Construction Industry In New Zealand. Auckland University of Technology.

Reason, P. (2006). Choice and Quality In Action Research Practice. Journal of Management Inquiry, 15(2), 187-203.

Zuber-Skerritt, O., \& Perry, C. (2002). Action Research Within Organisations And University Thesis Writing. The Learning Organization, 9(4), 171 -179. 